\title{
SOIL WATER DYNAMICS RELATED TO THE DEGREE OF COMPACTION OF TWO BRAZILIAN OXISOLS UNDER NO-TILLAGE ${ }^{(1)}$
}

\author{
Vanderlei Rodrigues da Silva ${ }^{(2)}$, José Miguel Reichert ${ }^{(3)}$, Dalvan José \\ Reinert $^{(3)}$ \& Edson Campanhola Bortoluzzi ${ }^{(4)}$
}

\begin{abstract}
SUMMARY
Soil water properties are related to crop growth and environmental aspects and are influenced by the degree of soil compaction. The objective of this study was to determine the water infiltration and hydraulic conductivity of saturated soil under field conditions in terms of the compaction degree of two Oxisols under a no-tillage (NT). Two commercial fields were studied in the state of Rio Grande do Sul, Brazil: one a Haplortox after 14 years under NT; the other a Hapludox after seven years under NT. Maps $(50 \times 30 \mathrm{~m})$ of the levels of mechanical penetration resistance (PR) were drawn based on the kriging method, differentiating three compaction degrees (CD): high, intermediate and low. In each CD area, the infiltration rate (initial and steady-state) and cumulative water infiltration were measured using concentric rings, with six replications, and the saturated hydraulic conductivity $\left(K_{(\theta s)}\right)$ was determined using the Guelph permeameter. Statistical evaluation was performed based on a randomized design, using the least significant difference (LSD) test and regression analysis. The steady-state infiltration rate was not influenced by the compaction degree, with mean values of 3 and $0.39 \mathrm{~cm} \mathrm{~h}^{-1}$ in the Haplortox and the Hapludox, respectively. In the Haplortox, saturated soil hydraulic conductivity was $26.76 \mathrm{~cm} \mathrm{~h}^{-1}$ at a low $C D$ and $9.18 \mathrm{~cm} \mathrm{~h}^{-1}$ at a high CD, whereas in the Hapludox, this value was $5.16 \mathrm{~cm} \mathrm{~h}^{-1}$ and $1.19 \mathrm{~cm} \mathrm{~h}^{-1}$ for the low and high CD, respectively. The compaction degree did not affect the initial and steady-state water infiltration rate, nor the cumulative water infiltration for either soil type, although the values were higher for the Haplortox than the Hapludox.

Index terms: water infiltration, mechanical penetration resistance, kriging, porosity.
\end{abstract}

\footnotetext{
(1) Parte da Tese de Doutorado do primeiro autor apresentada ao Programa de Pós-Graduação em Agronomia da Universidade Federal de Santa Maria - UFSM. Pesquisa realizada com recursos do CNPq e FAPERGS. Recebido para publicação em novembro de 2008 e aprovado em junho de 2009.

(2) Professor do Departamento de Agronomia da Universidade Federal de Santa Maria, Centro de Educação Superior do Norte RS, Campus de Frederico Westphalen - RS. CEP 98400-000 Santa Maria (RS). E-mail: vanderlei@smail.ufsm.br

(3) Professores do Departamento de Solos, Universidade Federal de Santa Maria - UFSM. Av. Roraima 1000, Camobi, CEP 97105900 Santa Maria (RS). Bolsista: Pesquisadores CNPq. E-mails: reichert@smail.ufsm.br; dalvanreinert@gmail.com

(4) Professor-Pesquisador Adjunto II da Faculdade de Agronomia e Medicina Veterinária, Universidade de Passo Fundo - UPF. Caixa Postal 611, CEP 99001-970 Passo Fundo (RS). E-mail: edsonb@upf.br
} 


\title{
RESUMO: DINÂMICA DA ÁGUA EM FUNÇÃO DO ESTADO DE COMPACTAÇÃO DE DOIS LATOSSOLOS BRASILEIROS SOB SISTEMA PLANTIO DIRETO
}

\begin{abstract}
As propriedades hidricas do solo relacionam-se com o crescimento das culturas e com aspectos ambientais e são influenciadas pelo estado de compactação do solo. Oobjetivo deste trabalho foi determinar, em campo, a infiltração de água e a condutividade hidráulica de solo saturado em função do estado de compactação de Latossolos sob sistema plantio direto (SPD). Duas áreas de lavouras comerciais do Rio Grande do Sul com dimensões de $50 \times 30 \mathrm{~m}$, foram estudadas: uma em um Latossolo Vermelho distrófico (LVd) cultivado por 14 anos em SPD; e a outra em Latossolo Vermelho distroférrico típico ( $L V d f)$ cultivado por sete anos em SPD. Mapas representando níveis de resistência mecânica do solo à penetração (RP) foram confeccionados utilizando-se o método da krigagem e, neles, foram identificados três estados de compactação (EC): maior, intermediário e menor. No campo, sobre cada faixa de EC, foram medidas, em seis repetições, a taxa de infiltração (inicial e estável) e a lâmina infiltrada acumulada de água, com auxílio de anéis concêntricos, e a condutividade hidráulica em solo saturado $\left(K_{(\theta s)}\right)$, com auxílio de permeâmetro de Guelph. A avaliação estatística foi realizada com base no delineamento inteiramente casualizado, empregando o teste da diferença mínima significativa (DMS) e a análise de regressão. A taxa de infiltração estável não variou entre os estados de compactação, com valor médio de $3 \mathrm{~cm} \mathrm{~h}^{-1}$ no $L V d$ e de $0,39 \mathrm{~cm} \mathrm{~h}^{-1}$ no LVdf. A condutividade hidráulica do solo saturado para o LVd foi de $26,76 \mathrm{~cm} \mathrm{~h}^{-1}$ no menor EC e de $9,18 \mathrm{~cm} \mathrm{~h}^{-1}$ no maior, ao passo que para o LVdf foi de 5,16 e $1,19 \mathrm{~cm} \mathrm{~h}^{-1}$, respectivamente para a menor e maior compactação. O estado de compactação não interferiu na taxa de infiltração inicial e estável nem na lâmina de água infiltrada acumulada de cada solo, porém os valores foram maiores para o LVd que para o LVdf.
\end{abstract}

Termos de indexação: infiltração de água no solo, resistência do solo à penetração, krigagem, porosidade.

\section{INTRODUCTION}

Compacted layers are frequently found in soils managed with no-tillage (NT), as a result of the history of heavy machine and implement traffic over the soil (Carter et al., 1999; Silva et al., 2007; Veiga et al., 2007). The natural accommodation of soil particles also favors the formation of compacted layers (Carvalho Jr. et al., 1998).

Compacted soil layers are easily identified by determining mechanical penetration resistance $(\mathrm{PR})$ by penetrographs, and by measuring the soil bulk density (Reichert et al., 2007). Nevertheless, these values vary due to innumerable factors, such as the crop type, soil clay content, the manner of conducting the experiment and the soil management system, as well as the soil water content (Klein et al., 1998; Reichert et al., 2007). Likewise, the critical value of mechanical penetration resistance, in other words, the value from where the problems for crop development begin, varies between $1 \mathrm{MPa}$ and $3.5 \mathrm{MPa}$ (Taylor et al., 1966; Merotto Jr. \& Mundstock, 1999). In spite of the wide range of $\mathrm{PR}$ values, $2 \mathrm{MPa}$ is seen as the critical value for penetration resistance for soil and crop conditions in general (Tormena et al., 1999).
In soils managed with no-tillage, $P R$ values are normally highest in the layer 0.08-0.12 m (Carter et al., 1999; Genro Jr. et al., 2004; Veiga et al., 2007; Reichert et al., 2009). For this reason, macroporosity and pore continuity in this layer are lower, which are important properties that define the soil water flow (Cousin et al., 1996; Bertol et al., 2004; Genro Jr. et al., 2009). In Brazilian soils, Tavares Filho et al. (2001) determined PR values between 2.24 and $3.54 \mathrm{MPa}$ as restrictive for root growth in two soil management systems. In Oxisols, a soil class with naturally large mineralogical variations (Schaefer et al., 2008), it would be expected that the hydraulic properties were affected differently, according to the state of soil compaction.

When soil compaction occurs at the surface, it represents a severe limitation to soil water infiltration, which will lead to erosion, even under no-tillage, where the presence of straw mulch favors water infiltration (Schäfer et al., 2001; Cassol \& Lima, 2003). Soil pores, responsible for retaining water in water field capacity, may be reduced even by light one-dimensional pressures, (Bortoluzzi et al., 2008), which has a negative effect on soil water dynamics and crop yield (Reichert et al., 2009). As a result thereof, White (1992) suggests the study of soil water infiltration as the appropriate physical-hydraulic property to 
represent the physical quality of a soil, for being responsive to the state of soil compaction also.

In this sense, estimates of the hydraulic properties under field conditions in relation to the different soil compaction degrees are fundamental. The spatial and temporal variability of soil water infiltration rate and saturated soil hydraulic conductivity $\left(\mathrm{K}_{\left(\theta_{\mathrm{s}}\right)}\right)$ is great and measurements are therefore difficult; however, they are important for understanding the soil-water relationship (Brito et al., 1996). The infiltration rate is strongly affected by soil surface characteristics, such as crop residues from farming, soil roughness and initial soil moisture, together with the network of continuous macropores at a depth that provides an increase in water infiltration capacity and in $\mathrm{K}_{(\theta \mathrm{s})}$ (Azooz et al., 1996; Barcelos et al., 1999). As a result, it is possible that water infiltration and $\mathrm{K}_{(\theta \mathrm{s})}$ values diminish as the CD increases and vary among different soils. Nevertheless, if this is not corroborated, compaction degree values should not be taken alone in order to assess the soil physical quality.

Therefore, the objective of this study was to determine water infiltration and hydraulic conductivity of saturated soil under field conditions in two Brazilian Oxisols under different compaction degrees.

\section{MATERIAL AND METHODS}

\section{Characteristics of the study location}

Two commercial fields in the medium altitude plateau of Rio Grande do Sul (RS) were used. The first area with a Haplortox (dystrophic Red Latosol) soil is located in Cruz Alta, RS (latitude $28^{\circ} 38^{\prime}$ South, longitude $53^{\circ} 36$ ' West, $494 \mathrm{~m}$ asl); while the other area with a Hapludox (dystroferric Red Latosol) soil is located in Coronel Barros, RS (latitude $28^{\circ} 22$ ' South, longitude $54^{\circ} 04^{\prime}$ West, $298 \mathrm{~m}$ asl) (Soil
Survey Staff, 1999; Embrapa, 2006). Both areas are on a hilltop, with a slope of less than one percent, and their soil classes are of great agricultural importance in the State. The climate in the region is humid subtropical, with no drought throughout the year, and an average temperature in the hottest month of $>22^{\circ} \mathrm{C}$ and of the coldest month of $>3{ }^{\circ} \mathrm{C}$ and $<18^{\circ} \mathrm{C}$.

The soils of this area had been farmed under a conventional cultivation system since the 1970 s, in the traditional crop rotation system of the region (corn/ oat/soybean/wheat). In the study period, the Haplortox has been used for a corn/soybean succession in the summer and wheat/oat associated with common vetch in the winter, under no-tillage for 14 years. In the second area, the Hapludox had been cultivated with only soybean in the summer and wheat or oat in the winter under no-tillage for 7 years.

\section{Identification of different soil compaction degrees in the areas}

In the crop areas, a plot of $50 \times 30 \mathrm{~m}$ was delimited for each soil and a $2 \times 5 \mathrm{~m}$ sampling grid was constructed, totaling 150 points for determination of PR. At each point, the PR was determined down to a depth of $0.40 \mathrm{~m}$, at intervals of $0.025 \mathrm{~m}$, using a penetrograph model SC-60 (cone, $12.83 \mathrm{~mm}$ diameter and $30^{\circ}$ angle). The PR values at a depth of $0.075 \mathrm{~cm}$ were analyzed as based on descriptive statistics: arithmetic mean, median, mode and coefficient of variation (Table 1 ).

Based on the data, semivariograms were determined of the spherical, exponential, linear and Gaussian type using $\mathrm{GS}^{+\circledR}$ software. The model was selected based on the greatest correlation coefficient obtained by the technique of cross validation. After selecting the best-suited variogram for the variable, the data were kriged to create PR maps. Kriging estimates PR values between the points which were observed, considering the properties of the semivariogram (Silva et al., 2004).

Table 1. Mean, median, mode, amplitude and coefficient of variation (CV) for values of penetration resistance (PR). Means of the layers 0-0.10 $\mathrm{m}$ and 0.10-0.20 $\mathrm{m}$ of two Brazilian Oxisols under no-tillage

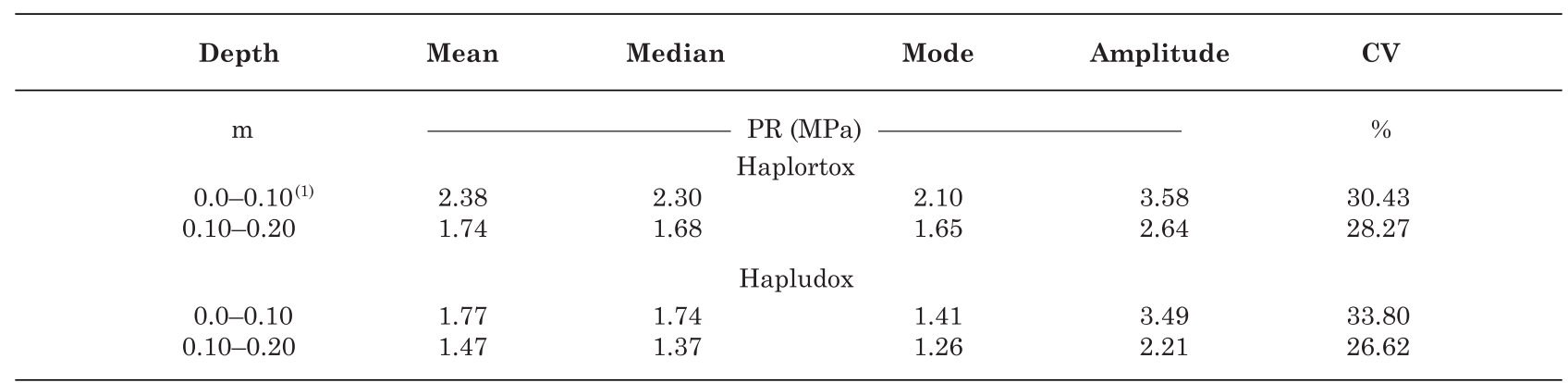

(1) Mean values of 3 depths and 150 observations (Silva et al., 2004). 
Based on the values of penetration resistance interpolated by kriging, three classes of compaction degrees (CD) were defined and mapped. With these maps, the three classes of compaction degrees were identified in the field, which were: high, intermediate and low. For the Haplortox, the PR intervals were, respectively, greater than or equal to $2.76 \mathrm{MPa}$, less than 2.75 and greater than or equal to $2.23 \mathrm{MPa}$, and less than $2.22 \mathrm{MPa}$; and for the Hapludox, greater than or equal to $2.11 \mathrm{MPa}$, less than 2.10 and greater than or equal to $1.60 \mathrm{MPa}$, and less than 1.59 MPa.

\section{Physical property measurements}

In the area of each soil, trenches (length, width and depth approximately $1.20 \times 1.50 \times 1.50 \mathrm{~m}$, respectively) were opened for collection and characterization of some soil physical attributes (Table 2). The samples were collected from different layers $(0-0.1,0.1-0.2,0.2-0.35 ; 0.35-0.5 ; 0.5-0.75 \mathrm{~m}$ and $0.75-1.0 \mathrm{~m}$ ), by soil sample rings.

Soil water infiltration was determined in six replications for each $\mathrm{CD}$ and each soil by the doublering infiltrometers, obtaining the cumulative water infiltration (I) and the steady-state infiltration rate (if for each CD and soil class. The methodological procedure consisted of inserting two concentric rings into the soil surface, one with a diameter of $0.4 \mathrm{~m}$ and the other of $0.2 \mathrm{~m}$ and a height of 0.15 . In both areas, a constant thin water layer of approximately $0.04 \mathrm{~m}$ was maintained at the soil surface and the volume infiltrated in the smaller cylinder was recorded until the infiltrated volume approached a steady value per time unit. Readings were inserted in the Kostiakov model to obtain the physical constants in accordance with equations 1 and 2 , respectively:

$$
\mathrm{I}=\mathrm{at} \mathrm{t}^{\mathrm{b}}
$$

where I is the cumulative water infiltration, $t$ is the time in minutes; $a$ is the infiltrated water layer during the first minute; $b$ is the tangent $d \mathrm{I} / \mathrm{dt}$ of the curve $\mathrm{I} * \mathrm{t}$.
Derived from equation 1 , expression 2 would be:

$$
\mathrm{i}_{\mathrm{f}}=\mathrm{c} \mathrm{t}^{-\mathrm{b}}
$$

where $i_{f}$ is the steady-state water infiltration rate; $c$ is the water infiltration when $t$ tends to zero (initial infiltration rate).

Hydraulic conductivity in saturated soil $\left(\mathrm{K}_{\left(\theta_{\mathrm{s}}\right)}\right)$ was determined in six replications at each $\mathrm{CD}$, using the Guelph constant head permeameter. The method consisted in opening a $0.15 \mathrm{~m}$ deep well with an auger. In this well, two hydraulic loads were applied; the first with a waterhead of $0.05 \mathrm{~m}$ and the second with a waterhead of $0.1 \mathrm{~m}$. At each hydraulic load, the level of the permeameter water reservoir was recorded every two minutes, until the water quantity infiltrated into the soil per time unit became steady. The $\mathrm{K}_{(\theta \mathrm{s})}$ was computed by the equations 3,4 and 5 , proposed by Ehlers (1975):

$$
\mathrm{K}_{(\theta \mathrm{s})}=\left(\mathrm{G}_{2} \mathrm{Q}_{2}\right)-\left(\mathrm{G}_{1} \mathrm{Q}_{1}\right)
$$

where $\mathrm{K}_{(\theta \mathrm{s})}$ is soil conductivity in a saturated condition, expressed in $\mathrm{cm} \mathrm{h}^{-1}$; and G1 and G2 are obtained by the equations:

$$
\begin{gathered}
\mathrm{G}_{2}=\mathrm{H}_{1} \mathrm{C}_{2} / \pi\left[2 \mathrm{H}_{1} \mathrm{H}_{2}\left(\mathrm{H}_{2}-\mathrm{H}_{1}\right)+\right. \\
\left.\mathrm{a}^{2}\left(\mathrm{H}_{1} \mathrm{C}_{2}-\mathrm{H}_{2} \mathrm{C}_{1}\right)\right] \\
\mathrm{G}_{1}=\mathrm{G}_{2}\left[\mathrm{H}_{2} \mathrm{C}_{1}\right] /\left[\mathrm{H}_{1} \mathrm{C}_{2}\right]
\end{gathered}
$$

where $\mathrm{a}$ is the radius of the well $(\mathrm{cm}) ; \mathrm{H}_{1}$ is the depth of the first waterhead $(0.05 \mathrm{~m}) ; \mathrm{H}_{2}$ is the depth of the second waterhead $(0.10 \mathrm{~m}) ; \mathrm{C}_{1}$ and $\mathrm{C}_{2}$ are factors corresponding to the ratio $\left(\mathrm{H}_{1} / \mathrm{a}\right)$ and $\left(\mathrm{H}_{2} / \mathrm{a}\right)$, respectively; E, Q1 and Q2 are obtained by the equations:

\begin{tabular}{|c|c|c|c|c|c|c|}
\hline \multirow{2}{*}{ CD } & \multirow{2}{*}{ PR intervals ${ }^{(1)}$} & \multirow{2}{*}{$\theta_{w}^{(2)}$} & \multirow{2}{*}{$\rho_{b}{ }^{(3)}$} & \multicolumn{3}{|c|}{ Particle-size distribution $^{(4)}$} \\
\hline & & & & Clay & Silt & Sand \\
\hline $\mathrm{k}$ & $\mathrm{MPa}$ & $\mathrm{g} \mathrm{g}^{-1}$ & $\begin{array}{c}\mathrm{Mg} \mathrm{m}^{-3} \\
\text { Haplortox }\end{array}$ & $\longrightarrow$ & $\mathrm{g} \mathrm{kg}^{-1}$ & - \\
\hline Low & 1.70 to 2.22 & 0.28 & 1.45 & 612 & 198 & 190 \\
\hline Intermediate & 2.23 to 2.75 & 0.26 & 1.52 & 532 & 241 & 227 \\
\hline High & 2.76 to 3.2 & 0.27 & 1.58 & 557 & 208 & 235 \\
\hline & & & Hapludox & & & \\
\hline Low & 0.20 to 1.59 & 0.21 & 1.38 & 609 & 297 & 94 \\
\hline Intermediate & 1.60 to 2.10 & 0.22 & 1.51 & 674 & 236 & 90 \\
\hline High & 2.11 to 2.8 & 0.23 & 1.55 & 576 & 312 & 112 \\
\hline
\end{tabular}

$$
\begin{aligned}
& \mathrm{Q}_{1}=(\mathrm{X}) \mathrm{R}_{1} \\
& \mathrm{Q}_{2}=(\mathrm{X}) \mathrm{R}_{2}
\end{aligned}
$$

Table 2. Mean values of some properties of two Brazilian Oxisols under no-tillage and different classes of compaction degrees (CD)

(1) Intervals of PR : penetration resistance. ${ }^{(2)} \theta_{w}$ : the gravimetric humidity of the soil at the time of collection. ${ }^{(3)} \rho_{b}$ : soil bulk density measured by soil sample rings. ${ }^{(4)}$ Particle-size distribution by the pipette method (Embrapa, 1997). Mean values of six observations of soil samples collected in the layers $0-0.1,0.1-0.2,0.2-0.35 ; 0.35-0.5 ; 0.5-0.75$ and $0.75-1.0 \mathrm{~m}$. 
where $\mathrm{X}$ is the area of the reservoir $\left(22.696 \mathrm{~cm}^{2}\right)$ and $R_{1}$ and $R_{2}$ is the constant infiltration rate in reservoir 1 and reservoir 2 , respectively.

The results were submitted to analysis of variance based on a randomized design with six replications. The means of the soils and compaction degrees were compared by the least significant difference (LSD) test at $5 \%$ error probability. Regression analysis was performed in the cases where the analysis of variance was significant for the quantitative factor only.

\section{RESULTS AND DISCUSSION}

\section{Effect of no-tillage on soil compaction degrees}

Penetration resistance (PR) of the two soils was summarized in table 1 . In summary, the PR values decrease from the first $(0-0.10 \mathrm{~m})$ to the second $(0.10$ $0.20 \mathrm{~m}$ ) layer. In the Haplortox, the mean PR in the layers $0-0.10 \mathrm{~m}$ and $0.10-0.20 \mathrm{~m}$ were 2.38 and 1.74 MPa, respectively, while for Hapludox, they were 1.77 and $1.47 \mathrm{MPa}$, equivalent to around two thirds of the first. According to Silva et al. (2004), who studied the spatial variability of PR in this area, this is due to the longer mechanical stress caused by 14 years under no-tillage, compared to seven years for the Hapludox, since the management and the granulometry of the soils were similar for both (Table 2). It is worth highlighting that the mean PR found in the areas were within a range of $1-3.5 \mathrm{MPa}$, in agreement with Merotto Jr. \& Mundstock (1999) and Souza et al. (2005), which results in alterations in the morphology of the root system of the plants grown in the areas (field observation). This situation shows that the PR values, even though discrepant, affect plant root growth, as also described by Taylor et al. (1966), Merotto Jr. \& Mundstock (1999) and Tavares Filho et al. (2001).

Nevertheless, elevated compaction degrees (CD) may be responsible for modifications of other physical soil properties, in addition to the increased soil penetration resistance (Cousin et al., 1996; Klein et al., 1998; Bertol et al, 2004; Tormena et al., 2007; Bortoluzzi et al., 2008). Different CD are a result of the management history of the areas, such as machinery traffic (Silva et al., 2000) and crop rotation (Lesturgez et al., 2004) and may cause modifications in the soil hydraulic properties. The porous space of the soil is negatively affected, altering the distribution of the pore size and connectivity among them, parameters that determine water storage and water flow in the soil (Cousin et al., 1996).

\section{Effect of soil compaction degrees on $I, i_{f}$ and, $\mathbf{K}_{(\theta \mathrm{s})}$}

A steady-state infiltration rate $\left(\mathrm{i}_{\mathrm{f}}\right)$ near $105 \mathrm{~cm} \mathrm{~h}^{-1}$ was observed in the Haplortox, and near $70 \mathrm{~cm} \mathrm{~h}^{-1}$ in the Hapludox (Figure 1). The rate declined rapidly in the two soils in an exponential response, until after about $30 \mathrm{~min}$, and stabilized after about $2 \mathrm{~h}$, at the end of the trials. More water infiltrated into the Haplortox soil per time unit during the entire trial (Figure 1).

There was no statistical interaction of the infiltration rate data with the different CD for the two soils, so a single Kostiakov equation of significant regression was determined, where the coefficient of determination was $\mathrm{r}^{2}=0.91$ for the Haplortox and $r^{2}=0.87$ for the Hapludox (Figure 1). Nevertheless, the steady-state infiltration rate in the Haplortox was similar at all compaction degrees (around $3 \mathrm{~cm} \mathrm{~h}^{-1}$ ), while in the Hapludox the value was around 10 times lower $\left(0.39 \mathrm{~cm} \mathrm{~h}^{-1}\right)$. It was concluded that the water infiltration rate was more dependent on the soil type and history of soil use than on the different CDs.

Similar to the infiltration rate, the cumulative water infiltration did not vary according to the CDs of the two soils (Figure 2). The values also fit a single equation for each soil type, based on the mean

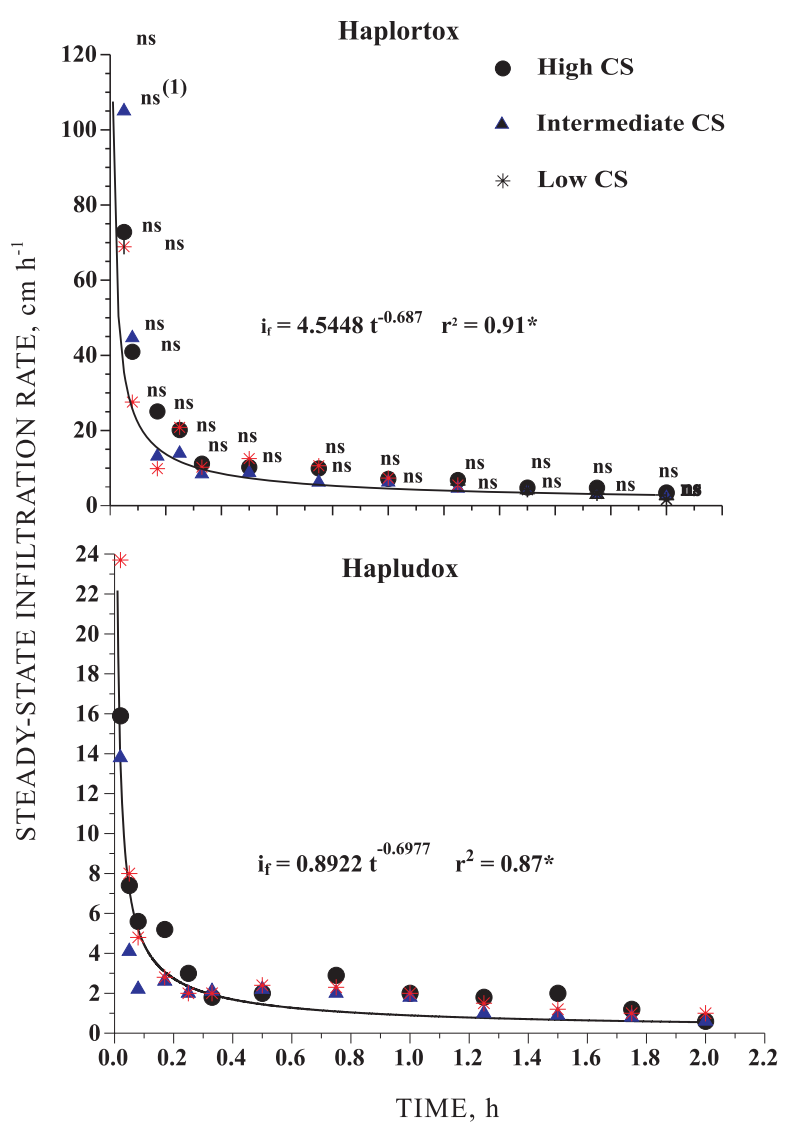

Figure 1. Steady-state infiltration rate (i), in time, at different compaction degrees (CD) of the soils Haplortox and Hapludox. Mean of six replications. Means of infiltration rate, in each time, do not differ significantly (ns) from each other by the LSD test $(p<5 \%)$. The regression equation corresponds to the mean of the compaction degrees. * significant at $5 \%$. 
cumulative water infiltration and the CD data. In the Haplortox, the water infiltration amount was around 45 and $10 \mathrm{~cm}$ and in the Hapludox, around $1 / 5$ of the first, in a 2-h period (Figure 2).

The CD of the soils, in spite of the wide range of mechanical penetration resistance, varied from over 2.76 MPa to less than 2.22 MPa for Haplortox and from over $2.11 \mathrm{MPa}$ to less than $1.59 \mathrm{MPa}$ for Hapludox. This did not affect the soil water dynamics significantly, i.e., the steady-state infiltration rate and cumulative water infiltration remained stable. This indicates that the water movement in the profile is also a result of the soil structure based on bulk density (Tormena et al., 2007), as well as pore quality (Cousin et al., 1996) and may therefore be influenced by soil management and compacted layers. The restrictive effect of these compacted layers on the water flow may be relieved by biological processes involving cover crops (Abreu et al., 2004), as long as the CD is not elevated to the point of limiting the root penetration of these plants (Reinert et al., 2008).

It is clear from this study that the level of mechanical penetration resistance may have different meanings for each soil type. This is probably the case because the PR values in the Hapludox were lower, including below the value considered critical, of $2 \mathrm{MPa}$, and the vertical water movement in this soil tends to be reduced. This allows the conclusion that the soil PR should be measured for each soil type, considering the nature and structure of its constituents.

For an adequate percolation of water into the soil, there should be no layers in the profile that impede water dynamics, since the steady-state water infiltration rate depends on the hydraulic conductivity $\mathrm{K}_{(\theta \mathrm{s})}$ of the layer of greatest impediment (Hillel, 1998).
The closer to the surface the obstructive layer, the greater will be the delay in the process of water infiltration into the soil. In the following, we sought to understand why water infiltration into the soil was not affected by the different CD. For this reason, the saturated hydraulic conductivity $\left(\mathrm{K}_{(\theta \mathrm{s}}\right)$ was measured.

In the Haplortox, the $\mathrm{K}_{(\theta \mathrm{s})}$ was in the mean $17.9 \mathrm{~cm} \mathrm{~h}^{-1}$, which is around five times higher than in the Hapludox, with $3.7 \mathrm{~cm} \mathrm{~h}^{-1}$ (Table 3). Nevertheless, separate soil analyses showed that in the Haplortox, the different CDs are responsible for the variation in $\mathrm{K}_{(\theta \mathrm{s})}$, while in the Hapludox there were no differences, most likely due to the high coefficient of variation obtained in the measurement of this parameter. In this sense, the greater the compaction degree in the Haplortox, the lower is the $\mathrm{K}_{(\theta \mathrm{s})}$ value. The $\mathrm{K}_{(\theta \mathrm{s})}$ values varied between 9.2, 17.6 and

Table 3. Values of hydraulic conductivity in saturated soil $\left(\mathrm{K}_{(\theta \mathrm{s})}, \mathrm{cm} \mathrm{h}^{-1}\right)$, measured in the field in two Brazilian Oxisols under no-tillage and different classes of compaction degrees (CD)

\begin{tabular}{lcc}
\hline Compaction states (CD) & Haplortox & Hapludox \\
& \multicolumn{2}{c}{$\mathrm{cm} \mathrm{h}^{-1}-$} \\
\cline { 2 - 3 } & $9.2 \mathrm{~b} \mathrm{~A}$ & $1.9 \mathrm{a} \mathrm{B}$ \\
High CD & $17.6 \mathrm{ab} \mathrm{A}$ & $3.9 \mathrm{a} \mathrm{B}$ \\
Intermediate CD & $26.8 \mathrm{a} \mathrm{A}$ & $5.2 \mathrm{a} \mathrm{B}$ \\
Low CD & 17.9 & 3.7 \\
Mean & 35 & 115 \\
Coeficient of variation (\%) & & \\
\hline
\end{tabular}

Means of six replications. Mean values followed by the same letter, lower-case letter in the column and capital letter in the row, do not differ from each other by the LSD test $(p<5 \%)$.
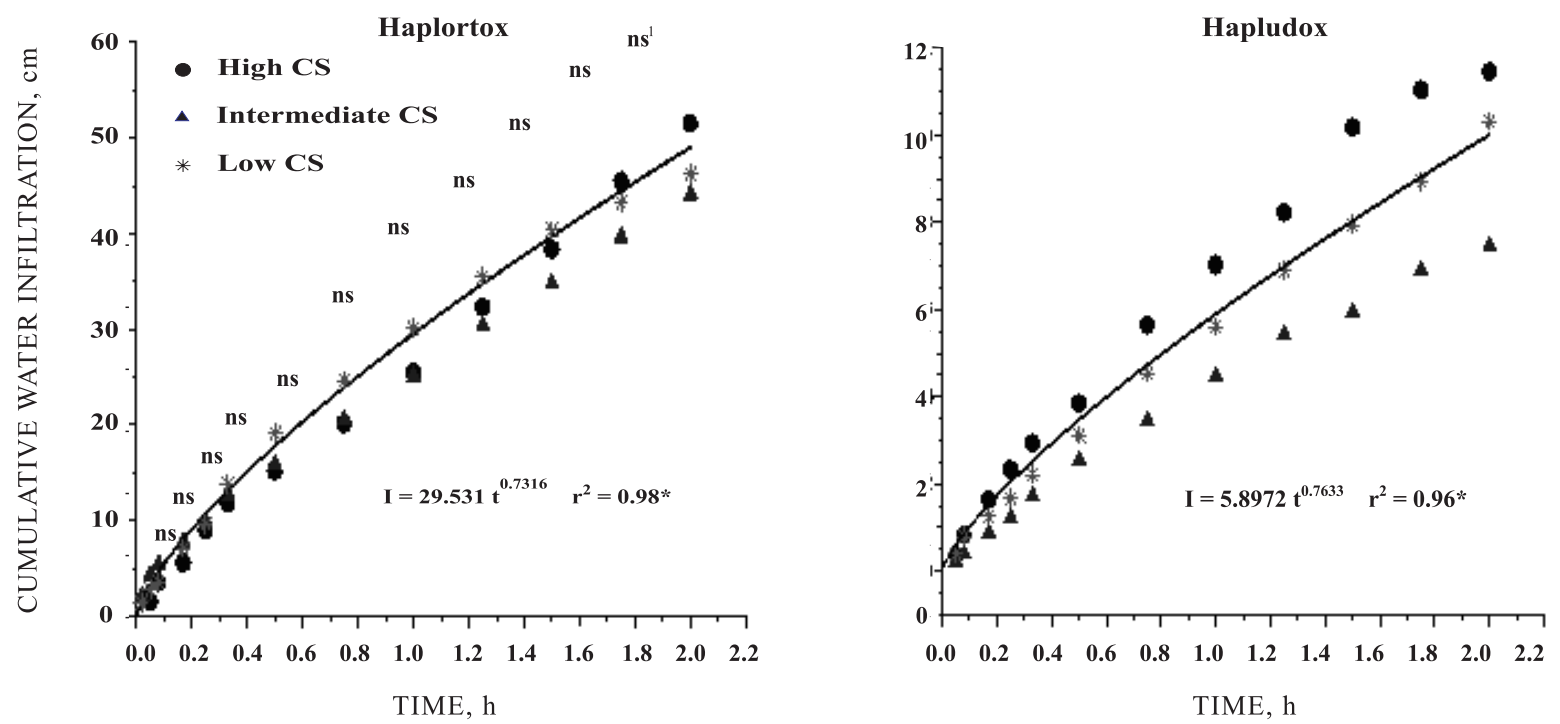

Figure 2. Mean values of cumulative water infiltration (I), in time, in different compaction degrees (CD) of the soils Haplortox and Hapludox. Mean of six replications. ${ }^{(1)}$ Means of infiltration rate, at each time point, do not differ significantly (ns) from each other by the LSD test $(\mathrm{p}<5 \%)$. The regression equation corresponds to the mean of the compaction degrees. *: significant at $5 \%$. 
$26.8 \mathrm{~cm} \mathrm{~h}^{-1}$, from the highest to the lowest compaction degree (Table 3), with differences only for the extreme values.

In agronomical terms, the compaction of a soil layer can diminish $\mathrm{K}_{(\theta \mathrm{s})}$, resulting in the need for drainage of excess water and maintenance of the soil productive potential by appropriate techniques (Beltrame et al., 1981). The consequence of compaction may be a longer period of waterlogged soil, which also reduces the time available to perform agricultural operations. This situation probably occurred in the Haplortox at the different CDs, however, without being reflected in the soil water dynamics. The $\mathrm{K}_{(\theta \mathrm{s})}$ values found in this study are around 10 times greater than those reported by Genro Junior et al. (2009) in a Hapludox, ranging from approximately 0.5 to $4 \mathrm{~mm} \mathrm{~h}^{-1}$, similar to the Hapludox in this study. The $\mathrm{K}_{(\theta \mathrm{s})}$ values varied from 0.25 to $1.63 \mathrm{~cm} \mathrm{~h}^{-1}$. Silva et al. (1986) observed a reduction of $\mathrm{K}_{(\theta \mathrm{s})}$ with the increase of the $\mathrm{CD}$ of two Oxisols, probably due to the reduction of the macropore quantity, which corroborates our results.

The hydraulic properties evaluated in the two soils allow inferences along two lines of thought. The first is related to the CDs in the two soils and the second to the meaning of the CD for the variables considered. In the Haplortox, under no-till cultivation for 14 years, the values of $\mathrm{PR}$ were around $30 \%$ greater at the high and intermediate CD and $40 \%$ higher at the low CD than in the Hapludox, with half of the time under NT (Table 3). It is possible that the CD is related to the management history of the areas, i.e., the more time under no-till, the greater the tendency of increasing soil penetration resistance.

The results found here are the outcome of the history of nearly 40 years of use and management, adding the periods of both conventional and no-till cultivation. When the results of studies regarding the soil properties under no-till are contrasted with soils under natural vegetation, a decrease can be observed, for example, in the quantity of infiltrated water in the soil (Kertzmann, 1996; Klein et al., 1998). The results of Kertzmann (1996) show this in Oxisol. The author verified that the steady-state infiltration rate, measured with concentric double cylinders in native vegetation, was $139.6 \mathrm{~cm} \mathrm{~h}^{-1}$ and was only $6.3 \mathrm{~cm} \mathrm{~h}^{-1}$ in an untilled area of intensive cultivation with little mulch after 15 years; in other words, there was a drastic, over 20 -fold reduction in soil water infiltration. Nevertheless, in the Haplortox this rate was $105 \mathrm{~cm} \mathrm{~h}^{-1}$, similar to that of the natural soil condition.

In this study, the results of both Oxisols under notill should be first contextualized according to the management conditions and the physical soil properties, even being similarly classified in the soil taxonomy (Schaefer et al., 2008); secondly, the meaning and consequence of the compaction degrees to other plant growth-related variables should be verified. The results here showed that in spite of the different compaction degrees which were found in the same soil, the soils differed from each other in the initial and steady-state infiltration rates.

\section{CONCLUSIONS}

1. Haplortox is $30 \%$ more resistant to penetration than Hapludox at the high and intermediate compaction degrees; however, compaction did not affect the initial and steady-state infiltration rate, although the values between the soils differed.

2 . The steady-state water infiltration rate and the hydraulic conductivity of saturated soil are influenced by the management system and soil type and were higher in the Haplortox than in the Hapludox.

\section{LITERATURE CITED}

ABREU, S.L.; REICHERT, J.M. \& REINERT, D.J. Escarificação mecânica e biológica para a redução da compactação em Argissolo franco arenoso em plantio direto. R. Bras. Ci. Solo, 28:519-531, 2004.

AZOOZ, R.H.; ARSHAD, M.A. \& FRANZLUEBBERS, A.J. Pore size distribution and hydraulic conductivity affected by tillage in Northwestern Canada. Soil Sci. Soc. Am. J., 60:1197-1201, 1996.

BARCELOS, A.A.; CASSOL, A.E. \& DENARDIN, J.E. Infiltração de água em um Latossolo Vermelho-Escuro sob condições de chuva intensa em diferentes sistemas de manejo. R. Bras. Ci. Solo, 23:35-43, 1999.

BELTRAME, L.F.S.; GONDIM, L.A.P. \& TAYLOR, J.C. Estrutura e compactação na permeabilidade de solos do Rio Grande do Sul. R. Bras. Ci. Solo, 5:145-149, 1981.

BERTOL, I.; ALBUQUERQUE, J.S.; LEITE, D.; AMARAL, A. \& ZOLDAN Jr, W.A. Propriedades físicas do solo sob preparo convencional e semeadura direta em rotação e sucessão de culturas comparadas às do campo nativo. R. Bras. Ci. Solo, 28:155-163, 2004.

BORTOLUZZI, E.C.; SILVA, V.R.; PETRY, C. \& CECCHETTI, D. Porosidade e retenção de água em um Argissolo sob plantio convencional e direto submetido a compressões unidimensionais. R. Bras. Ci. Solo, 32:1447-1457, 2008.

BRITO, L.T. de L.; LOVEREIRO, B.T.; DENICULI, W.; RAMOS, M.M. \& SOARES, J.M. Influência do método na determinação da velocidade de infiltração. R. Bras. Ci. Solo, 20:503-507, 1996.

CARTER, M.R.; ANGERS, D.A. \& TOPP, G.C. Characterizing equilibrium physical condition near the surface of a fine sandy loam under conservation tillage in a humid climate. Soil Sci., 164:101-110, 1999.

CARVALHO Jr, I.A.; FONTES, L.E.F. \& COSTA, L.M. Modificações causadas pelo uso e formação de camadas compactadas e/ou adensadas em um Latossolo VermelhoEscuro textura média, na região do Cerrado. R. Bras. Ci. Solo, 22:505-514, 1998. 
CASSOL, E.A. \& LIMA, V.S. Erosão em entressulcos sob diferentes tipos de preparo e manejo do solo. Pesq. Agropec. Bras., 38:117-124, 2003.

COUSIN, I.; LEVITZ, P. \& BRUAND, A. Three-dimensional analysis of a loamy-clay soil using pore and solid chord distributions. Eur. J. Soil Sci., 47:439-452, 1996.

EHLERS, W. Observations on earthworm channels and infiltration on tilled and untilled loess soil. Soil Sci., 119:242-249, 1975.

EMPRESA BRASILEIRA DE PESQUISA AGROPECUÁRIA EMBRAPA. Manual de métodos de análise de solo. Rio de Janeiro, 1997. 212p.

EMPRESA BRASILEIRA DE PESQUISA AGROPECUÁRIA EMBRAPA. Sistema brasileiro de classificação de solos. Brasília, 2006. 306p.

GENRO Jr., S.A.; REINERT, D.J.; REICHERT, J.M. \& ALBUQUERQUE, J.A. Atributos físicos de um Latossolo Vermelho e produtividade de culturas cultivadas em sucessão e rotação. Ci. Rural, 39:65-73, 2009.

GENRO Jr., S.A.; REINERT, D.J. \& REICHERT, J.M. Variabilidade temporal da resistência à penetração de um Latossolo argiloso sob semeadura direta com rotação de culturas. R. Bras. Ci. Solo, 28:477-484, 2004.

HILLEL, D. Environmental soil physics. San Diego, Academic Press, 1998. 771p.

KERTZMANN, F.F. Modificações na estrutura e no comportamento de um Latossolo Roxo provocados pela compactação. São Paulo, Universidade de São Paulo, 1996. 153p. (Tese de Doutorado)

KLEIN, V.A.; LIBARDI, P.L. \& SILVA, A.P. Resistência mecânica do solo à penetração sob diferentes condições de densidade e teor de água. Eng. Agríc., 18:45-54, 1998.

LESTURGEZ, G.; POSS, R.; HARTMANN, C.; BOURDON, E.; NOBLE, A. \& RATANA-ANUPAP, S. Roots of Stylosanthes hamata create macropores in the compact layer of a sandy soil. Plant Soil, 260:101-109, 2004.

MEROTTO Jr., A. \& MUNDSTOCK, C.M. Wheat root growth as affected by soil strength. R. Bras. Ci. Solo, 23:197-202, 1999.

REICHERT, J.M.; SUZUKI, L.E.A.S. \& REINERT, D.J. Compactação do solo em sistemas agropecuários e florestais: Identificação, efeitos, limites críticos e mitigação. In: CERETTA, C.A.; SILVA, L.S. \& REICHERT, J.M., eds. Tópicos em ciência do solo. Viçosa, MG, Sociedade Brasileira de Ciência do Solo, 2007.v.5.p.49134.

REICHERT, J.M.; SUZUKI, L.E.A.S.; REINERT, D.J.; HORN, R. \& HAKANSSON, I. Reference bulk density and critical degree-of-compactness for no-till crop production in subtropical highly weathered soils. Soil Till. Res., 102:242254, 2009.

REINERT, D.J.; ALBUQUERQUE, J.A.; REICHERT, J.M.; AITA, C. \& CUBILLA, M.M.A. Limites críticos de densidade do solo para o crescimento de raízes de plantas de cobertura em Argissolo Vermelho. R. Bras. Ci. Solo, $32: 1805-1816,2008$
SCHAEFER, C.E.G.R.; FABRIS, J.D. \& KER, J.C. Minerals in the clay fraction of Brazilian Latosols (Oxisols): A review. Clay Miner., 43:137-154, 2008.

SCHÄFER, M.J.; REICHERT, J.M.; REINERT, D.J. \& CASSOL, E.A. Erosão em entressulcos em diferentes preparos e estados de consolidação do solo. R. Bras. Ci. Solo, 25:431$441,2001$.

SILVA, A.P.; LIBARDI, P.L. \& CAMARGO, O.A. Influência da compactação nas propriedades físicas de dois Latossolos. R. Bras. Ci. Solo, 22:311-317, 1986.

SILVA, S.R.; BARROS, N.F.; COSTA, L.M.; MENDONÇA, E.S. \& LEITE, F.P. Alterações do solo influenciadas pelo tráfego e carga de um "forwarder" nas entrelinhas de uma floresta de eucalipto. R. Bras. Ci. Solo, 31:371-377, 2007.

SILVA, V.R.; REICHERT, J.M. \& REINERT, D.J. Resistência mecânica do solo à penetração influenciada pelo tráfego de uma colhedora em dois sistemas de manejo do solo. Ci. Rural, 30:795-801, 2000.

SILVA, V.R.; REICHERT, J.M. \& REINERT, D.J. Variabilidade espacial da resistência à penetração em plantio direto. Ci. Rural, 34:399-406, 2004.

SOIL SURVEY STAFF. Soil taxonomy: A basic system of soil classification for making and interpreting soil surveys. 2.ed. Washington, D.C., Natural Resources Conservations Service,. U.S. Department of Agriculture, 1999. 871p. (Agriculture Handbook, 436)

SOUZA, Z.M.; BEUTLER, A.N.; MELO, V.P. \& MELO, W.J. Estabilidade de agregados e resistência à penetração em Latossolos adubados por cinco anos com biossólidos. R. Bras. Sci. Solo, 29:117-123, 2005

TAVARES FILHO, J.; BARBOSA, G.M.C.; GUIMARÃES, M.F. \& FONSECA, I.C.B. Resistência do solo a penetração e desenvolvimento do sistema radicular do milho (Zea mays) sob diferentes sistemas de manejo em um Latossolo Roxo. R. Bras. Ci. Solo, 25:725-730, 2001.

TAYLOR, H.M.; ROBERTSON, G.M. \& PARKER, J.J. Soil strength root penetration relations for medium to coarse textured soil materials. Soil Sci., 102:18-22, 1966.

TORMENA, C.A.; ARAÚJO, M.A.; FIDALSKI, J. \& COSTA, J.M. Variação temporal do intervalo hídrico ótimo de um Latossolo Vermelho distroférrico sob sistemas de plantio direto. R. Bras. Ci. Solo, 31:211-219, 2007.

TORMENA, C.A.; SILVA, A.P. \& LIBARDI, P.L. Soil physical quality of a Brazilian Oxisol under two tillage systems using the least limiting water range approach. Soil Till. Res., 52, 223-232, 1999.

VEIGA, M.; HORN, R.; REINERT, D.J. \& REICHERT, J.M. Soil compressibility and penetrability of an Oxisol from Southern Brazil, as affected by long-term tillage systems. Soil Till. Res., 92:104-113, 2007.

WHITE, I. Tillage practices and soil hydraulic properties: Why quantify the obvious? In: LOVEDAY, J., ed. NATIONAL SOILS CONFERENCE, 1992. Review Papers. Canberra, Australian Society Soil Science, 1992. 